\title{
Muuttuva eläinsuhde Juri Rytheun tuotannossa
}

Tarkastelen artikkelissani, kuinka tšuktšikirjailija Juri Rytheu (1930-2008) kuvaa tuotannossaan neuvostoajan vaikutusta arktisen alueen inmisten ja eläinten väliseen suhteeseen. Rytheun teoksissa kysymys inmisen ja eläimen välisestä suhteesta kietoutuu laajempaan maailmankatsomukselliseen keskusteluun, mikä heijastelee alkuperäiskansan tasapainoilua oman maailmankatsomuksensa ja kommunistisen vallan ajaman materialistisen maailmankatsomuksen välillä. Eläimen kategoria avaa Rytheun tuotannossa myös koloniaaliseen "toiseuteen" liittyviä kysymyksiä. Lähestyn alkuperäiskansan eläinsuhteeseen kohdistuvaa muutospainetta Gayatri Spivakin (1988) "episteemisen väkivallan" käsitteen, postkoloniaalisen teorian sekä kulttuurisen eläintutkimuksen kautta. Kiinnitän artikkelissa huomiota myös siihen, kuinka eri vuosikymmenet vaikuttavat Rytheun tapaan käsitellä aihetta.

Eeva Kuikka

Ilmastonmuutoksen ja geopoliittisten kysymysten myötä arktisesta alueesta on tullut 2010-luvulla yksi ihmis- ja yhteiskuntatieteellisen tutkimuksen kärkikohteista (ks. esim. Ryall et al. 2010; Kraska 2011; Ray \& Maier 2017). ${ }^{1}$ Tämä on lisännyt akateemista kiinnostusta myös Venäjän arktista aluetta kohtaan. Yhtäältä kiinnostusta on herättänyt Venäjän geopoliittinen asema arktisena suurvaltana (esim. Hønneland 2017), toisaalta tutkimuksessa on tarkasteltu neuvostohallinnon toimenpiteiden vaikutuksia arktiseen luontoon ja alueen alkuperäiskansoihin (esim. Josephson 2014; Bruno 2016). Kirjallisuudentutkimuksen rooli Venäjän arktisen alueen tutkimuksessa on ollut toistaiseksi vähäinen. Arktiselle alueelle sijoittuvien ja erityisesti alueen alkuperäiskansojen edustajien kirjoittamien tekstien kautta voidaan kuitenkin valottaa paikallisten kokemusta arktisessa ympäristössä tapahtuneista muutoksista. Artikkelini tarkoitus onkin paikata omalta osaltaan tätä aukkoa. 
Tarkastelen, kuinka Venäjän pohjoiseen alkuperäiskansaan, tšuktšeihin, kuuluva kirjailija Juri Rytheu (1930-2008) käsittelee teoksissaan neuvostokolonisaation vaikutusta kotialueellaan Tšukotkan niemimaalla, Venäjän Kaukoidässä, asuvien alkuperäiskansojen, tšuktšien ja eskimoiden, elämään. Kyseisten alkuperäiskansojen perinteiset elinkeinot, poronhoito ja merinisäkkäiden pyynti, ovat sidoksissa alueen eläimiin ja eläimillä on alkuperäiskansoille merkitystä myös kansallisen identiteetin rakentajina. Tämän vuoksi tarkastelen neuvostokolonisaation vaikutusta nimenomaan alkuperäiskansojen eläimiin liittyviin käytäntöihin sekä pragmaattisella, elinkeinoihin liittyvällä, että symbolisella tasolla. Kiinnitän huomiota myös siihen, kuinka eläimen ja koloniaalisen "toisen" kategoriat limittyvät toisiinsa erityisesti Rytheun 2000-luvun tuotannossa. Tarkasteluni pohjaa sekä postkoloniaaliseen teoriaan että kulttuuriseen eläintutkimukseen ja näiden välisiin liittymäkohtiin. Lähestyn Rytheun tuotannossa kuvattua ihmisen ja eläimen ${ }^{2}$ välistä suhdetta neljästä eri suunnasta: šamanismista, sukupolvierosta, alkuperäiskansan ja valtakulttuurin maailmankatsomuksellisista eroista sekä toiseuden näkökulmasta.

Tyypillisesti postkoloniaalisen teorian avulla tarkastellaan kriittisesti eurooppalaisten harjoittamaa siirtomaapolitiikkaa. Kuitenkin kuten Ewa Thompson (2000) osoittaa, Venäjä kasvatti valtakuntaansa vastaavanlaisesti kolonisoimalla muille kansakunnille kuuluvia naapurialueita. Tästä huolimatta Venäjän maateitse tapahtuva levittäytyminen on jäänyt suurimmaksi osaksi postkoloniaalisen kritiikin sivuuttamaksi. Sen sijaan Neuvostoliiton naapurimaihinsa harjoittamaan kolonialismiin sekä jälkisosialismin ja postkolonialismin väliseen yhteyteen on 2000-luvulla alettu kiinnittää huomiota. ${ }^{3}$ Kuitenkin myös arktisilla alueilla Venäjän ja myöhemmin Neuvostoliiton harjoittama politiikka muistutti eurooppalaisten tapaa hyödyntää siirtomaitaan luonnonvarojen ja raaka-aineiden lähteenä (vrt. esim. Loomba 2005, 9).

Venäjän arktista aluetta voikin pitää Mary Louise Prattin (1992) kuvaamana kontaktialueena (contact zone), jossa kulttuurien väliset kohtaamiset luovat niiden välille epätasa-arvoisia ja hierarkkisia suhteita. Arktisesta alueesta muodostui neuvostodiskursseissa Edward Saidin (2011) kuvaamaa orienttia muistuttava alue, jota tuotettiin viranomaishallinnan, tieteen ja taiteen keinoin. Toisaalta arktinen alue ei Neuvostoliiton aikana, kuten ei sitä ennen tai sen jälkeenkään, ollut pelkkä staattinen diskurssi, vaan jatkuvasti erilaisissa vuorovaikutussuhteissa rakentuva tila. Tämän vuoksi näenkin hedelmällisenä lähestyä arktista aluetta Doreen Masseyn (2005) ajatusten kautta erilaisten toimijoiden välisissä suhteissa ja keskinäisessä vuorovaikutuksessa jatkuvasti muotoutuvana heterogeenisena tilana. Näin ollen tulkitsen myös Rytheun teoksissa kuvatun arktisen tilan muodostuvan moninaisissa vuorovaikutussuhteissa, joiden osapuolia ovat sekä viralliset diskurssit ja maailmankatsomukset että alkuperäiskansojen edustajat ja venäläiset, mutta myös eläimet, luonto ja moderni teknologia.

Arktisten alueiden hyödyntäminen tehostui Neuvostoliiton aikana 1920-luvulta alkaneen nopean modernisaation ja teollistamisen myötä vaikuttaen alueen alkuperäiskansojen elintapoihin sekä arktiseen luontoon (McCannon 1998; Josephson 2014; Bruno 2016). Erityisen voimakkaasti neuvostoaika vaikutti juuri tšuktšeihin, jotka olivat onnistuneet vastustamaan tsaarin valtaa ja säilyttäneet omat tapansa ja lakinsa venäläisten viranomaisten läsnäolosta huolimatta (Forsyth 1992, 143-151). Neuvostoliiton aikana ote alueesta ja alkuperäiskansoista kuitenkin kiristyi. Arktinen alue ja luonto miellettiin hyödyntämättömäksi resurssiksi, joka neuvostoihmisen tuli ottaa haltuunsa (Bolotova 2014), ja ajoittain "taistelua" arktista luontoa vastaan kuvattiin varsin sotaisankin retoriikan avulla (McCannon 1998, 82-89). Nopean teollistumisen ja modernisaation lisäksi arktisilla alueilla toteutettiin sinnikkäitä valistuskampanjoita, joiden tarkoituksena oli nostaa alkuperäiskansat primitiivisiksi mielletyistä 
olosuhteista modernin sivistyksen ja marxilaista materialismia edustavan kommunistisen maailmankuvan piiriin. Tämä tapahtui erityisesti koulutuksen kautta ja kieltämällä haitallisiksi mielletyt kulttuuriset käytänteet, kuten šamanismi (Forsyth 1992; Slezkine 1994). Neuvostovallan mukanaan tuomat muutokset näkyivätkin erityisesti nuoremmissa sukupolvissa luoden alkuperäiskansojen keskuuteen sisäoppilaitoksissa kasvatetun sukupolven, joka ei osannut alkuperäiskansojen kieltä, harjoittaa näiden perinteisiä elinkeinoja tai tuntenut muutenkaan oman kansansa kulttuuria (Slezkine 1994, 379-384). Neuvostoaikana tapahtuneiden muutosten vaikutusta alkuperäiskansojen luontosuhteeseen ja sen heijastumista kirjallisuuteen on tutkittu kuitenkin varsin vähän.

Juri Rytheu kuului niihin Koillis-Siperian alkuperäiskansoja edustaviin kirjailijoihin, jotka astuivat näyttävästi Neuvostoliiton kaunokirjalliselle kentälle 1950-luvulla kansojensa ensimmäisinä intelligentsijan edustajina. Kuten suurin osa pohjoisiin alkuperäiskansoihin kuuluvista kirjailijoista, myös Rytheu omaksui tapansa kuvata kansaansa ja kotialuettaan Neuvostoliiton virallisista pohjoisen ja arktisen alueen valloitusta korostavista diskursseista sekä varhaisemmasta venäläisten kirjailijoiden kirjoittamasta aluetta kuvaavasta kirjallisuudesta (Slezkine 1994, 327). Tämän vuoksi Rytheun erityisesti varhaisemman tuotannon voi nähdä noudattavan sosialistisen realismin konventionaalista tapaa kuvata arktisen alueen neuvostokolonisaatiota kertomuksena, jossa bolševikit johdattavat alkuperäiskansojen edustajat koulutuksen, kulttuurin ja materiaalisen hyvinvoinnin pariin. ${ }^{4}$ Rytheun asema alkuperäiskulttuurin ja valtakulttuurin välillä ei ole yksiselitteinen. Vaikka Rytheu vietti lapsuutensa kotonaan tšuktšikulttuurin ja -perinteiden ympäröimänä, sai hän venäläisen koulutuksen, asui koko aikuisikänsä Leningradissa ja kirjoitti suurimman osan tuotannostaan venäjän kielellä. ${ }^{5}$

Siitä huolimatta, että Rytheu on yksi Venäjän tunnetuimmista alkuperäiskansoihin kuuluvista kirjailijoista, on häntä tutkittu suhteellisen vähän. Kirjailijan tuotannolle omistettujen monografioiden (esim. Vlasenko 1988; Rogover \& Kolupaeva 2005) lisäksi akateemista mielenkiintoa ovat herättäneet Rytheun teosten genre sekä niissä esiintyvät aikakäsitykset (Kolupaeva 2006; Mørch 2017). Susi Frank (2016) puolestaan tarkastelee Rytheuta neuvostokirjallisuudelle ominaisen monikansallisuuden ideaalin näkökulmasta kiinnittäen huomiota "monikansallisen neuvostokirjallisuuden" anti-imperialistisen lähtökohdan ja imperialististen käytänteiden väliseen jännitteeseen. Suurinta keskustelua tutkijoiden parissa on herättänyt Rytheun tunnetuin teos Kun valaat lähtevät (Kogda kity uhodjav, 1975), jossa Rytheu poikkeaa aikaisemmasta realistisesta tyylistään palaten tšuktšien myyttiin omasta alkuperästään ihmisen ja valaan jälkeläisinä. Vaikka tutkijat (Mørch 2014; Hazankovitš 2007) nostavat esille, kuinka teos käsittelee ihmisen ja eläinten välistä suhdetta sekä ekologisia kysymyksiä, ei Rytheun muun tuotannon runsaaseen eläinkuvastoon ole kiinnitetty juurikaan huomiota. Rytheun tuotannon luoma kuva alkuperäiskansojen edustajien ja eläinten välisestä suhteesta ei ole kuitenkaan yksiselitteinen tai tiivistettävissä vain yhteen kaunokirjalliseen teokseen. Rytheun tuotannossa käsitelläänkin runsaasti niitä kulttuurisia ja yhteiskunnallisia muutoksia, joita alkuperäiskansan edustajien ja eläinten välisessä suhteessa Neuvostoliiton aikana tapahtui. Kuten artikkelissa kuitenkin osoitetaan, Rytheun tapa lähestyä näitä muutoksia vaihtelee vuosikymmenten saatossa saaden Neuvostoliiton hajoamisen jälkeen hyvinkin kriittisiä sävyjä.

Tarkastelen artikkelissani Rytheun teoksissa kuvattua valtakulttuurin saneleman maailmankatsomuksen ja eläinsuhteen omaksumisen tarvetta Gayatri Spivakin (1988) kuvaamana "episteemisenä väkivaltana"6. Episteemisellä väkivallalla Spivak tarkoittaa Foucault'n ajatuksia mukaillen länsimaisen yhteiskunnan ja tieteen tapaa vaientaa alistettuja väestöryhmiä muun muassa sivuuttamalla ja sortamalla näiden tietoa tai tietojärjestelmiä. Keskityn artikkelissani 
tarkastelemaan kolmea Rytheun kirjoittamaa teosta, pienoisromaania Harppuunanheittäjä (Metatelnitsa garpuna, 1971) ja romaaneja Toivon saari (Ostrov nadeždy, 1987) sekä Surun tähtikuvion alla (Pod sozvezdijem petšali, 2007). Kussakin teoksessa kuvataan keskeisesti neuvostovallan vaikutusta alkuperäiskansojen maailmankuvaan, mikä heijastuu näiden ja eläinten väliseen suhteeseen. Toisaalta kukin teoksista tuo esiin hieman erilaisia näkökulmia suhteessa kolonialismiin ja eläimiin. Teokset on kirjoitettu eri vuosikymmeninä ja eri vuosikymmenten yhteiskunnalliset tilanteet näkyvätkin Rytheun tavoissa lähestyä aihetta.

\section{Eläimet ja kolonialismi}

Eläinten ja kolonialismin väliset yhteydet eivät ole uusi tai ennenkuulumaton tutkimuskohde. Valtaosa kolonialismin ja eläinten välisten yhteyksien tutkimuksesta tarkastelee kuitenkin Amerikan mantereen kolonisaatiota. Huomiota on kiinnitetty siihen, kuinka eurooppalaiset karja- ja kotieläimet vaikuttivat alueen kolonisaatioprosessiin (Crosby 1986; Anderson 2004) ja kuinka kolonialismi, alkuperäisasukkaiden oikeudet ja eläimet kytkeytyvät yhteen pohjoisamerikkalaisissa juridisissa diskursseissa (Kanji 2018). Neuvostoliiton Siperiassa harjoittamaa kolonisaatiota lähestytään tutkimuksessa harvemmin erityisesti eläinnäkökulmasta. Koska pohjoisten alkuperäiskansojen elintavat ovat niin vahvasti sidoksissa erilaisiin eläinlajeihin, sisällytetään eläimet ja eläinsuhteissa tapahtuneet muutokset kuitenkin olennaiseksi osaksi Siperian alkuperäiskansojen kulttuuria käsittelevää etnografista tutkimusta (esim. Anderson 2000; Wiget \& Balalaeva 2011).

Koillis-Siperiassa Tšuktšien niemimaalla asuvat tšuktšit ovat perinteisiltä elinkeinoiltaan sisämaassa poronhoitajia ja rannikkoalueilla merinisäkkäiden metsästäjiä samoin kuin rannikkoalueella asuvat jupik-eskimotkin. ${ }^{7}$ Koska alkuperäiskansojen pääasialliset elinkeinot olivat sidoksissa eläimiin, muodostui alkuperäiskansojen edustajille kulttuurisesti merkittävimpiin eläimiin erityinen suhde, joka kytkeytyi kansojen animistiseen maailmankuvaan. Alueen neuvostokolonisaation myötä tapahtuneet modernisaatio, teollistuminen ja kollektivisaatio vaikuttivat kuitenkin alkuperäiskansojen tapaan toimia eläinten kanssa. Šamaanit, jotka olivat tärkeässä asemassa ihmisten ja eläinten välisessä kommunikaatiossa, eivät saaneet enää harjoittaa perinteisiä uhrimenoja. Kollektivisaatio rikkoi porojen ja poropaimenten välisen tiiviin suhteen ja neuvostoliittolainen tuotannon tehokkuuden ihanne sai nuoret metsästäjät luopumaan merinisäkkäiden ja näiden ruhojen ja luiden käsittelyyn liittyneistä perinteisistä ja symbolisesti merkittävistä tavoista kuten pyydettyjen eläinten luiden palauttamisesta takaisin mereen (Forsyth 1992, 369; Kerttula 2000, 133-134). Perinteen ja modernisaation pakottaman uudenlaisen ajattelun välinen ristiriita näkyy myös Rytheun tuotannossa, jossa alkuperäiskansojen edustajat joutuvat tasapainoilemaan oman maailmankatsomuksensa ja yhteiskunnan asettamien uusien mallien ja normien välillä.

Jälkikolonialistisessa kirjallisuudentutkimuksessa ja kulttuurisessa eläintutkimuksessa eläimiin on kiinnitetty huomiota kolonialististen diskurssien representaatioina. Esimerkiksi Jopi Nyman (2003) tarkastelee sitä, kuinka eläinnarratiivien kautta kirjallisuudessa ilmaistaan rodun, luokan, sukupuolen ja suurvaltioidentiteettien problematiikkaa usein tarkoituksena ylläpitää vallitsevaa sosiaalista järjestystä. Postkolonialistisessa kirjallisuudessa puolestaan erityisesti myyteistä ja kansanperinteestä nousevat eläinhahmot toimivat itserepresentaation välineenä (emt., 8-9). Kolonialismin ja eläinten voidaan nähdä kytkeytyvän yhteen myös eurosentrismin ja antroposentrismin (ihmiskeskeisyyden) sekä rasismin että spesismin (lajisorron) välisten yhteyksien kautta. Kuten Val Plumwood (2003) kirjoittaa, eurooppalaisten harjoittama kolonisaatio perustui antroposentriseen ajatukseen ihmisestä luonnosta erillise- 
nä, mikä johti ajatukseen ei-inhimillisen luonnon haltuun ottamisesta ja hyödyntämisestä myös Euroopan rajojen ulkopuolella. Tämä puolestaan johti ajatukseen alkuperäiskansoista luontoon ja eläimiin vertautuvina, epärationaalisina ja primitiivisinä ihmisryhminä, jotka tuli saattaa sivistyksen eli eurooppalaisen kulttuurin piiriin, joka samalla toimi myös ihmisyyden määreenä. Cary Wolfe $(2003,6)$ puolestaan muistuttaa, että eläimen sulkeminen ihmisyyden ulkopuolelle mahdollistaa niiden luvallisen tappamisen ja johtaa myös siihen, että sama mahdollisuus ulotetaan toisiin ihmisryhmiin luokittelemalla nämä eläimiksi. Graham Huggan ja Helen Tiffin (2010) tarkastelevatkin eläinten ja postkolonialismin suhdetta laajemmassa ekokriittisessä kontekstissa keskittyen juuri antroposentrisen ajattelun ja kolonialististen käytänteiden väliseen yhteyteen.

Edellä esitetyt ajatukset ovat sovellettavissa myös Rytheun tuotantoon. Vaikka tämän teoksissa ei muutamaa poikkeusta lukuun ottamatta ole varsinaisia eläinhahmoja tai -narratiiveja, ovat eläimet jatkuvasti läsnä osana arktista tilaa ja ympäristöä. Eläimet ovat merkittävä osa alkuperäiskansojen kulttuuria sekä symbolisella, kosmologisella että käytännön tasolla. Samanaikaisesti niistä tulee myös kolonialististen käytänteiden kohteita, kun ne otetaan osaksi luonnon ja eläinten välinearvoa korostavaa kulttuuria. Rytheun teoksissa voi myös nähdä kuinka alkuperäiskansojen rinnastaminen luontoon ja eläimiin "takapajuisuuden" ja "primitiivisyyden" käsitteiden avulla oikeuttaa näitä koskevat kolonialistiset ja jopa rasistiset käytänteet.

\section{Šamaanit inmisten ja eläinten välissä}

Kysymys arktisista alkuperäiskansoista, eläimistä ja episteemisestä väkivallasta kiteytyy tarkasteltavissa teoksissa šamaanin hahmoon, joka toimii alkuperäiskansojen oman kulttuurin, valtakulttuurin ja eläinmaailman välisenä leikkauspintana. Tšuktšien ja monien muiden arktisen alueen alkuperäiskansojen perinteessä šamaani oli henkilö, joka muiden tehtävien ohella hoiti myös ihmisten suhdetta ei-inhimilliseen luontoon. Neuvostoliiton valistuskampanjoiden ja antišamanistisen politiikan myötä šamaaneista tuli 1930-luvulla vainottuja kansanvihollisia (esim. Forsyth 1992, 287-290). Tämä näkyi myös kirjallisuudessa, jossa tyypillisin tapa kuvata šamaaneita oli korostaa näiden vilpillisyyttä ja roolia alkuperäiskansojen jäsenten hyväksikäyttäjinä (Znamenski 2003; Leete 2005). ${ }^{8}$ Tässä suhteessa šamaani onkin neuvostoaikana harjoitetun episteemisen väkivallan henkilöitymä: alkuperäiskansan tiedon välittäjä, joka modernin, ateistisen maailmankuvan tulon myötä muuttuu lainsuojattomaksi. Näin tapahtuu myös tarkastelemissani teoksissa. Šamaanit toimivat niissä ihmisen ja eläimen välisinä viestijöinä ja eläimiin liittyvän kulttuurisen tradition kantajina joutuen tasapainoilemaan oman maailmankatsomuksensa ja kommunistisen ideologian sekä modernin luonnontieteen välillä.

Koska eläimet ovat alkuperäiskansojen tärkein luonnonvara, joista riippuu myös näiden ravinnon saanti, nousevat maailmankatsomukselliset kysymykset esiin nimenomaan suhteessa eläimiin. Erityisesti metsästykseen liittyy lukuisia tapoja ja rituaaleja, joiden tehtävänä on taata metsästyksen onnistuminen ja tulevien saaliiden turvaaminen kiittämällä meren ja merinisäkkäiden jumalia sekä lepyttelemällä pyydystettyjen eläinten henkiä. Toivon saari -romaanissa šamaani Ierok kuvaa näkemystään metsästäjän ja eläimen välisestä suhteesta seuraavanlaisesti: 
Ierok selitti Ušakoville: - Me emme tapa karhua, vaan otamme vain sen lihan ja lämpimän turkin. Mutta jääkarhun sielu lähtee jäätikölle, kasvattaa uudelleen lihan ja turkin tullen jälleen oikeaksi, silminnähtäväksi eläimeksi. Se tulee meille ikään kuin vieraaksi ja meidän tulee viihdyttää ja ilahduttaa hyvällä vastaanotolla. Jos se viihtyy meidän luonamme, se palaa varmasti jälleen uuden lihan ja turkin kanssa. (Rytheu 1987, 127.) ${ }^{9}$

Kaikki eläimet eivät ole alkuperäiskansojen maailmankatsomuksessa yhtä merkittävässä asemassa, esimerkiksi venäläisten mukanaan tuomat siat herättävät kaikkiruokaisuudellaan eskimoissa inhotusta. Alkuperäiskansojen omiin kulttuureihin sidoksissa olevat eläimet kantavat puolestaan myös symbolista arvoa. Kysymys šamaanin roolista tšuktši- ja eskimoperinteiden säilyttäjänä nouseekin esiin erityisesti suhteessa tällaisiin kulttuurisesti symbolisiin eläimiin, kuten valaisiin ja jääkarhuihin. Näihin eläimiin liittyvät uskomukset ja säännöt eivät ole pelkkiä toimintatapoja tai metsästyskäytänteitä, vaan ne heijastavat alkuperäiskansojen maailmankatsomusta ja epistemologisia lähtökohtia. Kyseisiin eläimiin liittyvien šamanististen käytänteiden kieltäminen toimiikin episteemisen väkivallan muotona, joka tekee laittomaksi uskonnon harjoittamisen sijaan koko alkuperäiskulttuurin tietojärjestelmän. Kohtaukset, joissa šamaanit harjoittavat rituaaleja valaan tai jääkarhun kanssa kommunikoidakseen, kuvaavat sekä tarvetta saada yhteys näihin eläimiin että tarvetta säilyttää kyseisten rituaalien takana piilevä maailmankatsomus. Šamanististen käytäntöjen kieltämisen lisäksi symbolisiin eläimiin liitetty maailmankatsomus voidaan "päihittää" hyödyntämällä eläimiin liitettyä animistista näkemystä kuten venäläispäällikkö Georgi Ušakov tekee romaanissa Toivon saari. Hän surmaa jäk̈karhun, jonka saarella asuvat eskimot uskovat olevan saarella vallitsevan pahan hengen ruumiillistuma, ja osoittaa näin sekä symbolisesti että konkreettisesti bolševikkien ylivaltaa henkiolentoihin nähden.

Tarkastelemissani teoksissa neuvostovallan puolueoppi ja moderni luonnontiede marginalisoivat šamanismin ja sen myötä koko alkuperäiskansojen maailmankatsomuksen. Esimerkiksi Harppuunanheittäjässä kolhoosin edustajana toimiva vanha valaanpyytäjätšuktši joutuu toimittamaan šamaanin virkaa, kun tämän nuorempi kollega saa saaliikseen raskaana olevan naarasvalaan. Naarasvalaiden pyytäminen on tšuktšien perinteessä ehdottomasti kielletty, sillä legendan mukaan "äiti-valaat" "turvaavat meririistan saannin kaikille rannikoiden asukkaille" (Rytheu 1973, 70). Yhtäältä kohtaus näyttäytyy kritiikkinä tšuktšiperinteen ja -tiedon katoamista kohtaan. Valaan pyydystänyt nuori tšuktši tietää kyllä valaisiin liittyvistä säännöistä, mutta kokemattomuuttaan ja osaamattomuuttaan hän tappaa vahingossa kansakuntaansa symboloivan eläimen. Tilanteen vakavuutta korostaa tieto siitä, että perinteen mukaan tällaiseen hirmutekoon syyllistynyt metsästäjä tulisi surmata valaiden lepyttämiseksi. Toisaalta samainen kohtaus tuo esiin sen sisäisen ristiriidan, jota yritys elää sekä vanhojen normien että yhteiskunnan uusien vaatimusten mukaan tuottaa. Naarasvalaan tappamisen kaltainen onnettomuus edellyttää ongelman ratkaisua vanhojen, uskonnollisten rituaalien keinoin, mutta tällainen "šamanismiksi" luokiteltava toiminta sotii kolhoosin edustajan poliittista asemaa vastaan. Tilanteen ratkaisu tarjoaa mahdollisuuden säilyttää jalat molemmissa kulttuureissa: illalla vanhat valaanpyytäjät suorittavat valaan lepyttämiseksi tarvittavat uhrimenot ja seuraavana päivänä kolhoosin edustaja pyytää anteeksi harjoittamaansa šamanismia piirikomitean toimistossa. Anteeksipyynnöstä huolimatta vanhusten turvautuminen omiin tapoihinsa osoittaa vastarintaa perinteen tukahduttamista kohtaan ja tarvetta pitää kiinni omasta kulttuurista yhteiskunnan näkemyksestä huolimatta. 
Neuvostoliiton antišamanistisen politiikan lisäksi šamaanien edustama animistinen tapa suhtautua eläimiin on ristiriidassa modernin luonnontieteellisen maailmankatsomuksen kanssa. Romaanissa Surun tähtikuvion alla maailmankatsomukset joutuvat konkreettiselle törmäyskurssille nuoren šamaanin ja venäläisen biologin välisen konfliktin muodossa. Šamaani on metsästänyt jääkarhun, jonka pää määrätään biologille "tieteellisiä kokeita varten" (Rytheu 2007, 76). Jääkarhun pää edustaa šamaanille paitsi suhdetta kaadettuun eläimeen niin myös käsitystä ihmisen omasta asemasta koko kosmologisessa järjestyksessä. Jääkarhu on eskimoille arvostettu vieras, joka tuo lahjaksi turkiksen ja lihan. Eläimen pään on määrä valvoa metsästäjän kotona, että lahjaan suhtaudutaan sen edellyttämällä kunnioituksella. Jääkarhun päästä tuleekin šamaanin ja biologin edustamien maailmankatsomusten välinen taistelutanner. Sen sijaan, että šamaani tyytyisi tilanteeseen tai muuttaisi näkemystään, hän varastaa pään biologin varastosta ja suorittaa jääkarhun sielulle tarvittavat lepyttelytoimenpiteet. "Tieteellisen näytepalan" varastaminen ja hyödyntäminen "villeihin rituaaleihin" johtaa šamaanin karkotukseen, jotta muut eskimot eivät altistuisi "marksismi-leninismille vihamieliselle vastavallankumoukselliselle šamanistiselle ideologialle" (Rytheu 2007, 97, 93). Šamaanin edustama alkuperäiskansan maailmankatsomus julistetaan paitsi toissijaiseksi niin myös yhteiskunnallisesti haitalliseksi. Laittomaksi julistaminen ja eristäminen toimivatkin romaanissa episteemisen väkivallan äärimmäisenä muotona, jossa alkuperäiskansan tietoa ja kulttuuria ei ainoastaan marginalisoida vaan kielletään täysin.

\section{"Oikeanlainen asenne eläimiin"}

Pienoisromaanissa Harppuunanheittäjä Rytheu kuvaa ihmisten ja eläinten välisessä suhteessa tapahtuneita muutoksia 1960-luvun lopun Tšukotkassa. Neuvostovalta alueella on vakiintunut ja tšuktši-ja eskimokylien tilalle on perustettu kaupunkeja ja kolhooseja. Alkuperäiskansoihin kuuluvat nuoret on otettu venäläisen koulujärjestelmän piiriin ja venäläisissä kouluissa ja yliopistoissa nämä omaksuvat modernin, teollistuneen yhteiskunnan maailmankatsomuksen. Venäläinen koulutusjärjestelmä toimiikin näkemykseni mukaan pienoisromaanissa institutionalisoituneen episteemisen väkivallan välineenä. Kehitykseen ja edistykseen nojaten hegemonisessa asemassa oleva tietojärjestelmä syrjäyttää alkuperäiskansojen omat epistemologiset näkemykset (vrt. Pratt 1992, 61). Pienoisromaani havainnollistaa alkuperäiskansan nuorten muuttunutta maailmankuvaa suhteessa sukupolvien erilaisiin tapoihin toimia eläinten kanssa. Vanhemmat tšuktšit edustavat alkuperäiskansan omaan maailmankatsomukseen nojaavaa tapaa käsitellä eläimiä. Modernin, teollistuneen yhteiskunnan tavat omaksuneille nuorille eläimistä on puolestaan tullut ennen kaikkea tuotantovälineitä ja raaka-aineita. Toimintatapojen ja asenteiden väliset erot tulevat ilmi eri sukupolvien edustajien välisessä kanssakäymisessä ja nuorten pyrkimyksissä kehittää eläimiin perustuvia tuotantotapoja modernia tiedettä soveltamalla.

Tieteen lisäksi sukupolvien välinen ero suhteessa eläimiin pohjautuu myös kommunistiseen yhteiskuntajärjestelmään. Vanhempaan tšuktšisukupolveen kuuluvat suurten porolaumojen omistajat eivät kollektivisaation alkaessa luovuttaneet porojaan valtiolle, vaan pakenivat tundralle laumoinensa (ks. esim. Forsyth 1992, 339-340). Kulakeiksi leimatuista poronomistajista tuli šamaanien ohella bolševikkien jahtaamia kansanvihollisia, ja kirjallisuudessa heidät kuvattiin häikäilemättöminä ja julmina riistäjinä, jotka sortivat sekä naisia että heidän alaisuudessaan työskenteleviä köyhiä poropaimenia (Slezkine 1994, 296-297). Harppuunanheittäjän päähenkilön, nuoren eläinteknikoksi opiskelleen komsomolilaistšuktšin, isä 
on juuri tällainen poronomistaja, joka kieltäytyy luovuttamasta porojaan kollektiiville ja pakenee tundralle. Poronomistajan julmuutta korostaa se, että tiukan paikan tullen hän häätää ylimäääiset vaimonsa ja vastasyntyneen päähenkilön, Maša Tegrynen, keskelle tundraa kuolemaan. Bolševikkien pelastama Maša kieltäytyykin tunnustamasta poronomistajaa isäkseen, vaan pitää todellisina isinään opettajiaan sekä Leniniä. Pähahenkilön ja tämän isän välinen ideologinen ero leimaa teoksen sukupolvikokemusta ja sukupolvien välistä eroa suhteessa eläimiin. Sen sijaan, että tavat käsitellä eläimiä pohjautuisivat sukupolvelta toiselle periytyvään alkuperäiskansan omaan tietoon, ne perustuvat päähenkilön henkisten isien tietoon - puolueideologiaan ja moderniin tieteeseen.

Sukupolvien välinen ero eläintenhoitotavoissa nousee pienoisromaanissa esille erityisesti suhteessa turkistarhaukseen ja poronhoitoon. Turkiseläinten pyynti ei ole tšuktšikulttuurille vieras ilmiö, mutta vanhemman sukupolven edustajat vierastavat modernien ja teollistuneiden yhteiskuntien tapaa tarhata eläimiä. Häkeistään "surullisesti katselevat" turkiseläimet saavat metsästäjät protestoimaan ja jopa laskemaan eläimiä vapaaksi (Rytheu 1973, 22). Metsästäjille ongelma ei ole siinä, että eläimet tapetaan vaan siinä, että vankeudessa eläimiltä riistetään mahdollisuus rehelliseen kamppailuun metsästäjän kanssa. Eläimen ja metsästäjän välillä vallitseva tasa-arvo kuuluu olennaisesti tšuktšimetsästäjien käsitykseen oikeanlaisesta tavasta kohdata eläin. Perustellessaan turkistarhauksen järkevyyttä vanhoille metsästäjille Maša nojaa kommunistisen puolueen näkemykseen siteeraten Magadanskaja pravda -lehteä, jonka mukaan "turkistarhaus on maatalouden pidon korkein muoto" (Rytheu 1973, 22). Myöhemmin Maša toteaa myös, että luonnossa turkiseläinten on vaikeampi elää kuin tarhoissa, jossa näille voidaan taata "paratiisimaiset olosuhteet" (emt., 76).

Koulutuksesta ja luonnontieteelliseen maailmankuvaan perustavasta tiedosta tulee pohja, jonka mukaan turkistarhaus pyritään järjestämään. Kun Maša haluaa uudistaa erään kolhoosin tappiolliseksi osoittautunutta turkistarhatoimintaa, perustaa hän toimenpiteensä "tieteelliselle pohjalle" (emt., 155). Esitellessään ajatuksiaan piirikomitean venäläiselle pääsihteerille Maša kiteyttää ongelman seuraavanlaisesti: "Ihmisille täytyy opettaa oikeanlainen asenne eläimiin" (emt., 165). Mašan mukaan turkistarhojen työntekijöiden ongelmaa kuvastaa se, että nämä ovat nimenneet tarhaeläimet tunnustaen sen myötä eläinten subjektiviteetin ja luoden näihin henkilökohtaisen suhteen. ${ }^{10}$ Eläimille annetut nimet ovat vieläpä ihmisten nimiä, mikä alleviivaa työntekijöiden tapaa kohdata eläimet henkilöinä. Mašan tapa puhua eläimistä edustaa puolestaan toista ääripäätä, modernia maailmankuvaa, jossa eläimet näyttäytyvät elävien olentojen sijaan ihmisten tarkoitusperiin hyödynnettävinä resursseina (ks. esim. Franklin 1999). Harppuunanheittäjän päähenkilölle tarhaeläimet ovat tuotantovälineitä, joiden tieteelliseen tietoon perustuvalla hoidolla voidaan maksimoida näiden tarjoama tuotto. Hän vertaakin turkistarhausta metalliteollisuuteen rinnastaen häkkieläimet elollisten olentojen sijasta teräkseen ja muihin jalostettaviin metalleihin (Rytheu 1973, 156).

Tieteellistä tietoa käytetään pienoisromaanissa myös poronhoidon kehittämiseen. Neuvostoliittolaisen eläinlääketieteen rooli poronhoidon uudistajana nousee esille eläinteknikko Muhinin nuoruudenmuisteloissa. Vastavalmistunut nautoihin erikoistunut eläinteknikko lähetetään töihin porotilalle, vaikka hän on nähnyt poroja vain valokuvissa. Varsinainen poronhoidon opettelu tapahtuukin tundralla kokeneiden paimentolaistšuktšien avustuksella. Tässä suhteessa pienoisromaanissa konkretisoituu Ania Loomban (2005, 60-61) huomio, jonka mukaan kolonialistinen tiedontuotanto "kytkee sisäänsä jatkuvaa neuvottelua alkuperäiskansojen tiedon kanssa tai sen sisällyttämistä" osaksi tuotettavaa tietoa. Vaikka eläinteknikko saa venäläisessä yliopistossa tieteellisen koulutuksen karjanhoitoon, tarvitsee 
hän alkuperäiskansan osaamista voidakseen soveltaa kyseistä tietoa tundralla. Kuitenkaan alkuperäiskansan tieto poronhoidosta ei kykene estämään poroprikaatissa tapahtuvaa porojen joukkomenehtymistä. Kesken talven lauhtuva pakkanen sulattaa lumen, mutta uudelleen kiristynyt pakkanen jäädyttää jäkälän kiinni maahan. Porot eivät saa sitä syödyksi, vaan kuolevat nälkään. Tapahtuma saa nuoren eläinteknikon suunniltaan ja tämä peräänkuuluttaa tarvetta osoittaa luonnolle ihmisen ylivoimaisuutta: " - Ei tällaista saisi tapahtua! Täytyy keksiä jotain sellaista, että ihminen olisi tundran todellinen isäntä!" (Rytheu 1973, 162). Ratkaisu löytyy tieteestä, "uusimmista eläinteknisistä varusteista, kastelulaitteista ja kemiallisista valmisteista" (emt., 163), joiden avulla Muhinin poroprikaati selviää keväästä alueen pienimmillä vasatappioilla. Näin ollen pienoisromaani antaa ymmärtää, että alkuperäiskansan tieto vaatii lisäkseen modernia tiedettä ja teknologiaa, jotta ihminen voi nousta voittajaksi suhteessa luontoon ja eläimiin.

Kuten Josephson (2014, 208-215) osoittaa, modernin teknologian ja eläinlääketieteen vieminen tundralle ei ollut useinkaan sellainen menestyskertomus kuin Rytheun Harppuunanheittäjä antaa ymmärtää. Suuria, pienillä alueilla pidettäviä porolaumoja vaivasivat sekä huonolaatuisesta ravinnosta johtuvat taudit että muunlaiset epidemiat, joiden edessä tutkijat olivat neuvottomia. Rytheun Harppuunanheittäjässä kuvaama tarve soveltaa modernia tiedettä poronhoidon tehostamiseksi heijasteleekin Neuvostoliitossa vallinnutta ajatusta ihmisestä luonnon herrana. Tieteen esittäminen poronhoitoa kehittävänä, positiivisena ilmiönä on myös keino oikeuttaa porolaumojen kollektivisointi ja poronhoidon tuominen alkuperäiskansan käytännöistä modernin yhteiskunnan ehtojen sanelemaksi. Luonnontieteen ulottaminen koskemaan alkuperäiskansan perinteistä elinkeinoa voidaan nähdä Prattia $(1992,31)$ mukaillen kolonialistisena käytäntönä, jossa siirtomaan luonto ilmiöineen sulautetaan tieteen kautta länsimaisen järjestyksen piiriin.

Pienoisromaanin välittämä näkemys vanhemman tšuktšisukupolven tiedosta ei ole kuitenkaan yksinomaan kielteinen tai vähättelevä. Vanhemmat tšuktšit toimivat alkuperäiskansan kulttuurin säilyttäjinä ja välittävät perinteitä venäläisissä kouluissa kasvaneille nuorille. Harppuunanheittäjän päähenkilö korostaakin, että tšuktšien legendat ja perinteet ovat olennainen osa alkuperäiskansan historiaa. Pienoisromaanissa näkyy Forsythin (1992, 365) huomio siitä, kuinka toisen maailmansodan jälkeen jopa kannustettiin elvyttämään aikaisemmin tukahdutettuja alkuperäiskansojen perinteitä, kunhan ne irrotettiin šamanistisiksi mielletyistä uskomuksista ja käytänteistä. Vaikka tšuktšien legendat, tanssit ja tavat välitetään nuoremman sukupolven edustajille, teoksessa ne riisutaan siitä maailmankatsomuksesta, johon ne ovat olleet kiinnittyneinä. Hyvänä esimerkkinä tästä toimii kohtaus, jossa pienoisromaanin päähenkilö suorittaa metsästysretkelle lähteneen miespuolisen ystävänsä apuna kotiin jäävän vaimon perinteisen tehtävän. Tapojen mukaan kotona odottava nainen "juottaa" miehen saaliiksi saamat eläimet kastamalla niiden kuonon veteen osoittaakseen kunnioitusta eläimen hengelle. Päähenkilölle kyseisen tavan noudattaminen ei liity šamanismiin tai uskoon siihen, että eläimellä olisi sielu, vaan kyse on alkuperäiskansan vanhan tavan säilyttämisestä ja siirtämisestä sukupolvelta toiselle. Vaikka alkuperäiskansan eläimiin liittyvät tavat jäävätkin jossain määrin elämään modernin koulutuksen saaneiden tšuktšien keskuudessa, perinteet menettävät niihin kuuluneen maailmankatsomuksellisen viitekehyksen.

\section{Dialogia vai tietolähteitä?}

Alkuperäiskansan perinteisen maailmankatsomuksen ja neuvostoliittolaisen modernin maailmankatsomuksen välillä tasapainoilu leimaa myös 1980-luvun lopulla julkaistun Toivon 
saari -romaanin kuvauksia ihmisen ja eläimen välisestä suhteesta. Romaani kuvaa 1920-luvun historiallista tapahtumaa, kun venäläinen tutkimusmatkailija Georgi Ušakov perustaa Jäämerellä sijaitsevalle Wrangelin saarelle siirtokunnan mukanaan joukko Koillis-Siperian rannikolla asuneita eskimoita. Siinä missä 1970-luvulla julkaistussa Harppuunanheittäjässä ei avata alkuperäiskansan eläinsuhteen takana piileviä maailmankatsomuksellisia kysymyksiä, kuvataan 1987 julkaistussa Toivon saaressa eskimoiden maailmankatsomusta hyvinkin yksityiskohtaisesti. Tämä heijastelee yleisempää muutosta Neuvostoliiton alkuperäiskansojen edustajien kirjoittamassa kirjallisuudessa: monien muiden pohjoisen pieniin kansoihin (malotšislennyje narody severa) kuuluvien kirjailijoiden tavoin Rytheu palasi jo 1970-luvulla hyödyntämään teoksissaan tšuktšilegendoja ja muuta alkuperäiskansan kulttuuriperimää (Barker 1993; Slezkine 1994, 364-371). Aiempaa positiivisempi suhde alkuperäiskulttuureihin heijastuu tapaan, jolla Toivon saaressa kuvataan eskimoiden maailmankatsomusta. Tämä näkyy myös siinä, että venäläisen tutkimusmatkailijan kanssa keskustelevat nimenomaan eskimoyhteisön šamaanit. 1930-luvun kirjallisuuden suuresta luokkavihollisesta tehdään 1980-luvun romaanissa alkuperäiskansan kulttuurisen tiedon säilyttäjä.

On olennaista huomata, että romaanin tapahtumat sijoittuvat aikaan ennen Neuvostoliiton 1930-luvulla harjoittamaa aggressiivista "sivistyspolitiikkaa". Tuolloin neuvostoviranomaiset aloittivat mittavat toimenpiteet alkuperäiskansojen "takapajuisuuden" nujertamiseksi pyrkien kitkemään alkuperäiskansojen omaan kulttuuriin viittaavat käytännöt ja korvaamaan ne "edistyksellisellä" neuvostokulttuurilla (Slezkine 1992). Teoksen sijoittaminen 1920-luvulle mahdollistaa Ušakovin ja eskimoiden välisen vuoropuhelun, jossa myös alkuperäiskansan oma maailmankatsomus ja tieto ympäröivästä luonnosta ja eläimistä näyttäytyvät relevanttina tapana hahmottaa maailmaa. Toisaalta teoksen tapahtuma-aikaan ja kulttuurien väliseen vuoropuheluun voi nähdä sisältyvän myös kritiikkiä 1930-luvulla suoritettua "valistustyötä" kohtaan. Ušakov korostaa kuinka alkuperäiskansojen maailmankatsomusta tulee lähestyä hienotunteisesti, mutta 1980-luvun lopun lukija tietää, että siihen puututtiin juuri niin "karkeasti ja tahdittomasti” (Rytheu 1987, 226) kuin mitä tutkimusmatkailija pelkääkin.

Vaikka Ušakovin ja eskimoiden maailmankatsomukselliset keskustelut kuvataan tasa-arvoisina, voidaan Ušakovin kanssa keskustelevia šamaaneja pitää Spivakin $(1999,6)$ kuvaamina "tietolähteinä" (native informant). Tällainen tietolähde edustaa Spivakin mukaan länsimaisen filosofisen tradition marginalisoimaa hahmoa, jonka kautta filosofia rakentaa sekä itseään että länsimaista subjektia. Käsite ei ole Spivakille vain teoreettinen väline. Lukiessaan intialaisen kirjailijan Mahasweta Devin novellia "Pterodactyl, Puran Sahay o Pirtha" (1965) Spivak (emt., 142) määrittelee tällaisiksi tietolähteiksi sellaiset alkuperäiskansojen edustajat, jotka selittävät omaa maailmankatsomustaan valtakulttuurin edustajille. Tilannetta voikin verrata myös Ušakovin ja eskimoiden välisiin keskusteluihin. Sen lisäksi, että romaanin šamaanit voidaan tulkita Spivakin määrittelemiksi tietolähteiksi, koskettaa ilmiö myös Juri Rytheuta itseään. Spivakin (emt., 270) mukaan osa intialaisen eliitin edustajista toimi tietolähteinä länsimaisille "toisen äänestä" kiinnostuneille intellektuelleille. Vastaavasti Rytheu edustaa kansallista suosiota nauttivana kirjailijana oman alkuperäiskansansa eliittiä, minkä lisäksi hän esittelee teoksissaan kansansa kulttuuriperintöä venäläiselle lukijakunnalle.

On myös syytä muistaa, että alkuperäiskansoille luotu kulttuurieliitti palveli Neuvostoliitossa ennen kaikkea alkuperäiskansojen sivistämistavoitetta toimimalla kansojensa "tiedostavana etujoukkona" matkalla kohti sivistystä (Slezkine 1994, 180). Näin ollen Rytheun kaksijakoinen tehtävä alkuperäiskansaa edustavana neuvostokirjailijana oli yhtäältä edustaa venäläisen lukijakunnan silmissä oman alkuperäiskansansa kulttuuria ja toisaalta todistaa

12 IDÄNTUTKIMUS $2 / 2019$ 
valtakulttuurin hyödyllisyyttä alkuperäiskansojen edustajille. Tämän kaksoisroolin voi nähdä heijastuvan Rytheun tapaan korostaa teoksissaan kulttuurien välistä dialogia ja selittää alkuperäiskulttuuria valtakulttuurin hyväksymien diskurssien avulla. Susi Frank $(2016,206)$ kritisoikin Rytheun universalistista tapaa nähdä neuvosto- ja alkuperäiskulttuurit ulkoisista eroista huolimatta toisilleen "käännettävissä" olevina. Toisaalta Rytheun tarvetta löytää keskusteluyhteys kulttuurien välille voidaan pitää osoituksena eräänlaisesta kaksoistietoisuudesta (double consciousness, ks. Du Bois 1969, 45), sisäisestä ristiriidasta alkuperäiskulttuurin ja valtakulttuurin välillä. Kysymys Rytheun identiteetistä kahden kulttuurin välissä tasapainoilevana hahmona on kuitenkin moniulotteisuutensa vuoksi oma tutkimusaiheensa ja liian laaja tullakseen kattavasti käsitellyksi tässä artikkelissa.

Toivon saari -romaani havainnollistaa alkuperäiskulttuurin ja valtakulttuurin välisen dialogin ongelmallisuutta ihmisen ja luonnon välistä suhdetta koskevan keskustelun kautta. Avatessaan Ušakoville maailmankatsomustaan eskimot altistavat sen hegemonisen valtakulttuurin tekemille tulkinnoille ja arvottamiselle. Tämä ei välttämättä tarkoita negatiivista tulkintaa alkuperäiskansojen maailmankatsomuksesta. Esimerkiksi Vlasenko (1988, 129-130) kirjoittaa, kuinka Toivon saaren kuvaukset alkuperäiskansojen maailmakatsomuksesta esittelevät eskimoiden ympäröivää luontoa koskevaa tietoa. Kyseinen tieto tulkitaan kuitenkin Ušakovin ajatusten kautta hänen pohtiessaan syitä eskimoystäviensä ajatuksille ja toiminnalle. Tämänkaltainen tapa "oikeuttaa" alkuperäiskansojen maailmankatsomus on ongelmallinen siinä mielessä, että se soveltaa länsimaisia kulttuurisia käsityksiä toisen kulttuurin näkemysten ja tapojen lukemiseen (Said 2011, 22). Tämä johtaa siihen, että toisen kulttuurin maailmankatsomuksesta hyväksytään omaan maailmankatsomukseen sovitettavissa olevat elementit, kun taas itselle vieraat piirteet torjutaan "takapajuisuuteen" tai "taikauskoisuuteen" vedoten. Rytheun romaanissa tätä tyypillisempää on oikeuttaa eskimokulttuurin maailmankatsomus romantisoinnin kautta "jalon villin" tai "ekologisen intiaanin" trooppeja mukaillen. Eskimoiden tieto näyttäytyy alkukantaisena ja mystisenä yhteytenä luonnon kanssa, jonka "sivistynyt" moderni maailma on kehittyessään menettänyt. Takapajuinen tai romantisoitu - alkuperäiskansa näyttäytyy venäläiselle tutkimusmatkailijalle yhtä kaikki kulttuurisena "toisena", jota vasten Ušakov peilaa omaa modernia, rationaalista ja tieteellistä maailmankuvaansa (vrt. Said 2011, 47).

Esimerkkinä alkuperäiskansan kulttuurin arvottamisesta länsimaisesta perspektiivistä käsin toimii eskimoiden tapa viettää viisipäiväisiä seremonioita jokaisen kaadetun jääkarhun kunniaksi. Aluksi Ušakov pitää kyseistä tapaa ajanhaaskauksena, joka kielii alkuperäisasukkaiden luontaisesta laiskuudesta. Ajan mittaan hän päättelee metsästystauon suojelevan alueen eläinpopulaatioita ja takaavan eläinten riittämisen metsästyskaudesta toiseen. Tavan ymmärtäminen edellyttääkin venäläiseltä sen tulkitsemista valtakulttuurissa hyväksyttävien diskurssien avulla. Spivak (1994) pitää alkuperäiskansojen kielen sivuuttamista eräänä näiden hiljentämisen muotona. Vaikka Spivak käyttää esimerkkinään konkreettista kieltä, saman ilmiön voi nähdä tapahtuvan käännettäessä alkuperäiskansan kulttuuria valtakulttuurille ymmärrettäväksi. Molemmissa tapauksissa valtakulttuuri luo käsityksen puheena olevasta ilmiöstä siinä uskossa, että alkuperäiskansa on tullut kuulluksi, vaikka "toiselle" ei ole luotu diskursiivista tilaa olla oma itsensä. Esimerkki paljastaa myös, kuinka valtakulttuurin arvojen siirtäminen alkuperäiskansan tapoihin johtaa niiden "kehittämiseen" eli korvaamiseen omilla kulttuurisilla käytännöillä. Ušakov esimerkiksi ymmärtää alkuperäiskansojen tarpeen pitää eläinpopulaatiot elinvoimaisina, mutta näkee eläinkantojen selvittämisen ja niiden koon hallinnan modernin tieteen tehtävinä. Näin ollen alkuperäiskansan kulttuurinen käytäntö 
alistetaan kolonialista diskurssia tukevalle luonnontieteelle. Alueen kartoittaminen ei ole kuitenkaan ainoastaan luonnontieteilijöiden tehtävä. Eläinlajien ja luonnon lisäksi Ušakov mieltää myös alkuperäiskansan kulttuurin, tavat ja uskomukset tieteellisen tutkimuksen ja kartoituksen kohteeksi. Alkuperäiskansojen kulttuurista tuleekin venäläispäällikön silmissä samanlainen valkoisen miehen tutkimuskohde kuin alueen luonnosta.

\section{Paluu Toivon saarelle}

Vuonna 2007 julkaistussa Surun tähtikuvion alla -romaanissa Rytheu palaa Toivon saaressa kuvaamalleen Wrangelin saarelle. Surun tähtikuvion alla sijoittuu Ušakovin lähdön jälkeiseen aikaan 1930-luvulle alkuperäiskansojen kulttuureihin kohdistuvien sivistystoimenpiteiden ja šamaanien vainojen ollessa kovimmillaan. Romaani kuvaa despoottimaisen päällikkö Sementšukin ja tämän alaisuudessa työskentelevien venäläisten toimien tuhoisia seurauksia Wrangelin saaren eskimoiden parissa. Kirjan eskimohahmot ovat pääasiassa tuttuja Toivon saaren lukijoille ja jatko-osaa muistuttava asetelma tarjoaa hedelmällisen lähtökohdan 1920-luvun ja 1930-luvun tapahtumien vertailuun. Mikäli venäläisten ja alkuperäiskansan edustajien välit esitetään vielä 1920-luvulla lämpiminä ja molemmin puolin kunnioittavina, 1930-luvulle sijoittuva teos paneutuu maailmankatsomusten ja valta-asetelmien yhteentörmäyksestä aiheutuviin kipukohtiin, alkuperäiskansoihin liitettyihin ennakkoluuloihin sekä eskimoihin kohdistuvaan rasismiin. Surun tähtikuvion alla -romaanilla ja muulla 2000-luvun tuotannollaan Rytheu ottaa osaa alkuperäiskansojen kohtaloa kriittisesti tarkastelevaan kirjallisuuteen, jonka yksi tunnetuimmista nimistä on hantikirjailija Jeremei Aipin (s. 1948). Rytheun uusimpien romaanien tavoitteena onkin alkuperäiskansojen historian uudelleentarkastelu, sillä alkuperäiskansojen 2000-luvun tilanteeseen hän ei ota teoksissaan kantaa.

Surun tähtikuvion alla -romaanissa eskimoiden maailmankatsomukseen kohdistuva episteeminen väkivalta kytkeytyy avoimeen rasismiin. Molemmat väkivallan muodot kiinnittyvät alkuperäiskansan eläinsuhteeseen. Yhtäältä se sivuutetaan sitä ymmärtämättä ja toisaalta sen kautta oikeutetaan alkuperäiskansaan kohdistuva syrjintä. Rytheu hyödyntääkin romaanissaan muun muassa Plumwoodin (2003) tekemää havaintoa siitä, kuinka kolonialistiset diskurssit oikeuttavat toiseutettujen väestönryhmien syrjinnän rinnastamalla nämä eläimiin. Rytheun romaanissa eskimoiden tapa elää hyödyntämällä alueen eläimiä sekä ravintona että käyttöesineissä toimii venäläisten silmissä osoituksena näiden alkukantaisuudesta ja kehittymättömyydestä:

Ja mitä tuli tasa-arvoon eskimoiden kanssa, sen hän [venäläispäällikkö Sementšuk] tunnusti tietenkin teoriassa... Mutta halusipa hän nähdä sen teoreetikon, joka julistaisi tasa-arvoa sellaisten ihmisten kanssa, jotka asuivat pilaantuneelta, hapantuneelta hylkeenrasvalta lemuavissa eskimomajoissaan, pukeutuivat täitä kuhiseviin taljoihin, elivät aaltojen rannalle heittämistä ajopuista kootun vaivaisen nuotion tai rasvalla toimivan kivilampun valossa ja syleilivät naisia, jotka eivät koskaan peseytyneet... Menkööt tämä tasa-arvotaistelija jäl̈lle paleltumaan ja yrittämään turhaan vaania hyljettä tai jääkarhua, palatkoon sitten majaansa, jossa saisi syödäkseen parhaassa tapauksessa puoliraakaa lihaa taikka koirien ruuaksi tarkoitettua kopalhenia. ${ }^{11}$ (Rytheu 2007, 112.)

Alkuperäiskansan tiivis yhteys ja riippuvaisuus eläinkunnasta yhdistyvät venäläisten silmissä likaisuuteen, pesemättömyyteen ja pelkoon loiseläimistä, minkä vuoksi eskimot 
eivät ole tervetulleita syömään ruokalassa venäläisten kanssa tai saunomaan venäläisille tarkoitetussa saunassa. Alkuperäiskansan eläimelliseksi miellettävä primitiivisyys tekee näistä eläinten kaltaisia absoluuttisia "toisia". Paikoitellen eskimot ovat venäläisten silmissä arvoltaan jopa eläimiä alempana: heidän kulttuurinsa ja elintapansa eivät kelpaa tieteellisen tutkimuksen kohteeksi toisin kuin alueen merinisäkkäät. Myös eskimoiden säästämät ruokavarastot venäläiset takavarikoivat omien vetokoiriensa ruuaksi. Nälkää näkevät eskimot ovat toisarvoisia koirien rinnalla, joita tarvitaan ympäri saarta kohdistuvien tutkimusretkien mahdollistamiseksi. Venäläisten koirat ovatkin työpanoksellaan osa neuvostoliittolaista arktisen alueen valloitusta, kun taas alkuperäiskansa toimii pikemminkin neuvostoihmisen hyötykäyttöön valjastamana luonnonvarana.

Neuvostoliiton hajoamisen jälkeen julkaistussa romaanissa Rytheulla on mahdollisuus osoittaa, kuinka eskimoiden eläinsuhteeseen kohdistuva episteeminen väkivalta johtaa alkuperäiskansan selviytymisen kannalta tuhoisiin seurauksiin. Surun tähtikuvion alla -romaanissa venäläispäällystön ymmärtämättömyys ja piittaamattomuus alkuperäiskansan luonnonkierron sanelemaa elämänrytmiä kohtaan riistävät eskimoilta mahdollisuuden valmistautua talven tuloon pyytämällä mursuja lihaksi varastoon. Kuten Virginia Anderson (2004, 32-33) osoittaa Pohjois-Amerikan kolonisaatiota esimerkkinään käyttäen, alkuperäiskansojen eurooppalaisille vieraat tavat hyödyntää eläimiä toimivat eurooppalaisille osoituksena näiden sivistyksen puutteesta. Venäläisten silmissä puolestaan eskimoiden luonnonkierron mukaan ajoittuva metsästyskausi on osoitus näiden laiskuudesta, vaikka historian saatossa muovautunut elämänrytmi on taannut eskimoille mahdollisuuden selvitä sukupolvesta toiseen. Romaanissa lihavarastojen puuttuminen johtaakin eskimoiden keskuudessa nälkäkuolemiin, jotka tuovat lukijalle väistämättä mieleen neuvostovallan Ukrainassa 1930-luvulla aiheuttaman nälänhädän, holodomorin. Rytheun kuvaama tapaus osoittaa, kuinka tiiviisti eskimokansan eläimiin liittyvät tavat ja tieto ovat yhteydessä näiden selviytymiseen arktisella alueella ja kuinka näiden sivuuttaminen johtaa lopulta alkuperäiskansan tuhoutumiseen.

Myös Patrick Wolfe (2006) rinnastaa alkuperäiskansan kulttuurin ja käytäntöjen tuhoamisen kansanmurhaan. Wolfe (emt., 398) kritisoi Raphael Lemkinin termiä kulttuurinen kansanmurha (cultural genocide) siitä, että se luo helposti vastakkainasettelun abstraktin kulttuurisen ja todellisemmaksi määrittyvän biologisen kansanmurhan välille. Wolfe korostaa (emt., 398-399), että "kulttuuriseen kansanmurhaan" sisältyvien käytäntöjen riistäminen vaikuttaa konkreettisesti alkuperäiskansojen kykyyn selviytyä hengissä- aivan kuten Rytheu osoittaa Surun tähtikuvion alla -romaanissaan. Tapa, jolla Rytheu kietoo romaanissa yhteen episteemisen väkivallan, šamaanien karkotuksen, eskimoiden nälänhädän ja venäläisten harjoittaman rasismin osoittaa, kuinka tiiviisti nämä väkivallan ja alistamisen muodot kuuluvat yhteen ja konkretisoituvat suhteessa alueen eläimiin. Arktisen alueen eläimet ja alkuperäiskansan tapa toimia niiden kanssa ovat edellytys paitsi fyysiselle selviytymiselle niin myös kansojen kulttuurisen identiteetin säilymiselle.

Vaikka ihmisen ja eläimen välinen suhde kietoutuu Rytheun teoksissa kysymyksiin tiedosta ja maailmankatsomuksista, Rytheun kirjallisessa äänessä on tapahtunut vuosikymmenten aikana muutoksia suhteessa näihin teemoihin. Rytheun neuvostoaikana kirjoittamissa teoksissa korostetaan alkuperäiskansojen ja neuvostovallan maailmankatsomusten välistä vuoropuhelua. Taustalla häilyy kuitenkin jatkuva tietoisuus alkuperäiskansan maailmankatsomuksen ja tiedon katoavasta luonteesta. Alkuperäiskansojen tieto ja maailmankatsomus näyttäytyvät osana kansojen historiaa, johon teoksissa suhtaudutaan yhtäältä kunnioittavasti mutta toisaalta myös myötäillen neuvostoyhteiskunnan modernisaation ihannetta. Tämä 
johtaakin helposti alkuperäiskansojen luontosuhteen romantisointiin ja sen tulkitsemiseen modernin yhteiskunnan arvoja mukaillen. Tällöin esimerkiksi alkuperäiskansojen tavat toimia eläinten kanssa menettävät niihin kytkeytyneen animistisen maailmankuvan ja näyttäytyvät puhtaasti ekologisiin motiiveihin perustuvina käytänteinä. 2000-luvun tuotannossaan Rytheu palaa 1930-luvun tapahtumiin ja alkuperäiskansoihin kohdistuneeseen "sivistyspolitiikkaan" korostaen alkuperäiskansan kulttuuriin ja tietoon puuttumisen väkivaltaista luonnetta. Tämä näkyy myös Rytheun tavassa kuvata alkuperäiskansojen suhdetta eläimiin, jossa käytännön tarpeen rinnalle nousee eläinten kulttuurinen merkitys. Kuten Rytheun viimeiseksi romaaniksi jäänyt Surun tähtikuvion alla osoittaa, tšuktšien ja eskimoiden tavat toimia eläinten kanssa ovat muutakin kuin pelkkiä toimintamalleja. Ne ovat olennainen osa alkuperäiskansojen kulttuurista identiteettiä ja ne heijastavat alkuperäiskansojen maailmankatsomusta ja näkemystä kosmologisesta järjestyksestä.

\section{Viitteet}

1 Artikkeli on kirjoitettu osana Suomen Akatemian rahoittamaa The Changing Environment of the North -projektia (hankenumero SA307840).

2 Vaikka käytän tässä artikkelissa termiä "eläimet" eläintutkimuksessa usein käytetyn termin "eiinhimilliset eläimet" sijaan, jaan jälkimmäiseen termiin kytkeytyvän ajatuksen ihmisestä yhtenä eläinlajina muiden joukossa. Olen päätynyt kuitenkin tähän, jotta en termivalinnoillani toisi Rytheun teosten luentaan sellaisia lisämerkityksiä, joita niistä itsestään ei voi päätellä.

3 Tästä keskustelusta ks. erityisesti Smola \& Uffelmann 2016.

4 Yuri Slezkine (1994, 292-293) kutsuu tämänkaltaista juonirakennetta nimellä "pitkä matka" (long journey). Käsitteellä hän viittaa sosialistisen realismin luomaan narratiiviin, jolla kuvataan alkuperäiskansojen harppausta kivikautiseksi mielletystä takapajuisuudesta kommunistien tarjoamiin "sivistyneen maailman" olosuhteisiin. Rytheuta Slezkine (emt., 364) kutsuukin tällaisten "pitkien matkojen" kirjoittamisen mestariksi.

5 Kulttuurien välisestä suhteesta Rytheun tuotannossa ks. Barker 1993.

6 Kiitos käsitteen tuomisesta tietoisuuteeni kuuluu Jopi Nymanille.

7 Rytheu itse kuului nimenomaan rannikolla eläviin tšuktšeihin, mutta kaunokirjallisessa tuotannossaan hän ei tee suurtakaan eroa rannikolla asuvien tšuktšien ja eskimoiden kulttuurien välille. Rannikolla asuvat eskimo- ja tšuktšiyhteisöt olivat todellisuudessakin tiiviisti tekemisissä sekä keskenään että paimentolaisten kanssa ja yhteisöjen välisten avioliittojen ohella merkittäväksi tekijäksi muodostui rannikkokylien ja poronhoitajayhteisöjen välinen kaupankäynti (Krupnik \& Chlenov 2013, 134-150). Tšuktšit ja eskimot elivät omissa kyläyhteisöissään, kunnes sovhoosien perustaminen johti sekä poronhoitaja- että rannikkotšuktšien ja eskimokylien yhdistämiseen (emt., 294-296; Forsyth 1992, 366-367).

8 Rytheun tuotannossa antagonistit eivät ole tyypillisesti šamaaneja vaan suurien porolaumojen omistajia, kuten Loke romaanissa Pienten jänisten laaksossa (V doline malenkyh zaitšikov, 1962), tai Kuuraa kynnyksellä (Inej na poroge, 1970) -romaanin Armagyrgin ja tämän kaima romaanissa Ikiroudan loppu (Konetš vetšnoi merzloty, 1977). Myös alueella toimivat amerikkalaiset kauppiaat kuvataan Rytheun teoksissa poikkeuksetta alkuperäiskansoja petkuttavina roistoina.

9 Kaikki artikkelissa esiintyvät käännökset ovat omiani. 
10 Turkistarhan työntekijöiden etninen tausta ei käy Rytheun tekstistä suoraan ilmi, mutta koska päähenkilö pohtii aikaisemmin mielessään tšuktšimetsästäjien alanvaihtoa turkistarhaukseen, on oletettavaa, että mainitut työntekijät ovat tšuktšeja.

11 Kopalhen on kesän aikana maakuopassa fermentoitunutta merinisäkkään lihaa, jota arktisten alueiden asukkaat syövät talven aikana. Romaanissa venäläispäällikkö Sementšuk ottaa nimenomaan eskimoiden edellisvuotiset kopalhen-varastot koiriensa ruuaksi.

\section{Kirjallisuus}

Anderson, David G. (2000), Identity and Ecology in Arctic Siberia: The Number One Reindeer Brigade. Oxford: Oxford University Press.

Anderson, Virginia (2004), Creatures of Empire: How Domestic Animals Transformed Early America. Oxford: Oxford University Press.

Barker, Adele (1993), The Divided Self: Yuri Rytkheu and Contemporary Chukchi Literature. - Between Heaven and Hell: The Myth of Siberia in Russian Culture. Eds Galya Diment \& Yuri Slezkine. New York: St. Martin's Press, 215-226.

Bolotova, Alla (2014), Conquering Nature and Engaging with the Environment in the Russian Industrialized North. Academic Dissertation. University of Lapland.

Bruno, Andy (2016), The Nature of Soviet Power: An Arctic Environmental History. New York: Cambridge University Press.

Crosby, Alfred (1986), Ecological Imperialism: Biological Expansion of Europe, 900-1900. Cambridge: Cambridge University Press.

Du Bois, W. E. B. (1969), The Souls of Black Folk. New York: The New American Library.

Forsyth, James (1992), A History of the Peoples of Siberia: Russia's North Asian Colony 1581-1990. Cambridge: Cambridge University Press.

Frank, Susi K. (2016), "Multinational Soviet Literature": The Project and Its Post-Soviet Legacy in Iurii Rytkheu and Gennadi Aigi. - Postcolonial Slavic Literatures after Communism. Eds Klavdia Smola \& Dirk Uffelmann. New York: Peter Lang, 191-218.

Franklin, Adrian (1999), Animals and Modern Cultures: a Sociology of Human-Animal Relations in Modernity. London: Sage.

Hazankovitš, Julija (2007), Na poroge haosa. Žanrovaja spetsifika sovremennoi legendy Ju. Rytheu "Kogda kity uhodjat". - Tšukotskaja literatura. Materialy i issledovanija. Sost. Vjatšeslav Ogryzko. Moskva: Literaturnaja Rossija.

Hønneland, Geir (2017), International Politics in the Arctic: Contested Borders, Natural Resources and Russian Foreign Policy. London: I.B. Tauris.

Huggan, Graham \& Tiffin, Helen (2010), Postcolonial Ecocriticism: Literature, Animals, Environment. London: Routledge.

Josephson, Paul R. (2014), The Conquest of the Russian Arctic. Cambridge: Harvard University Press.

Kanji, Azeezah (2018), Colonial Animality: Constituting Canadian Settler Colonialism through the Human-Animal Relationship. - Critical Epistemologies of Global Politics. Eds Marc Woons \& Sebastian Weier. Bristol: E-International Relations Publishing, 63-78.

Kerttula, Anna M. (2000), Antler on the Sea: the Yup'ik and Chukchi of the Russian Far East. Ithaca: Cornell University Press.

Kolupaeva, Marina Viktorovna (2006), Problematika i žanrovoje svojeobrazije romanov Jurija Rytheu 80-h godov XX veka. Avtoreferat. Rossiski gosudarstvennyi pedagogitšeski universitet imeni A. I. Gertsena. Sankt-Peterburg, 30.1. https://search.rsl.ru/en/record/01003259611

Kraska, James (ed.) (2011), Arctic Security in an Age of Climate Change. Cambridge: Cambridge University Press. 
Krupnik, Igor \& Chlenov Michael (2013), Yupik Transitions. Change and Survival at Bering Strait, 1900-1960. Fairbanks: University of Alaska Press.

Leete, Art (2015), Reconsidering the Role of Shamans in Siberia during the Early Soviet Era. - Shaman 23:1-2, 61-80.

Loomba, Ania (2005), Colonialism/Postcolonialism (2nd edition). London: Routledge.

Massey, Doreen (2005), For Space. London: SAGE.

McCannon, John (1998), Red Arctic: Polar Exploration and the Myth of the North in the Soviet Union, 1932-1939. New York: Oxford University Press.

Mørch, Audun (2014), The Chronotope of the Promordial: Yuri Rytkheu's When the Whales Leave. - Nordlit 32, 17-32. https://doi.org/10.7557/13.3078.

Mørch, Audun (2017), Between the Primordial, the Modern and the Post-Modern: The Chukchi Writer Yuri Rytkheu. - Arctic Modernities: The Environmental, the Exotic and the Everyday. Eds Heidi Hansson \& Anka Ryall. Newcastle upon Tyne: Cambridge Scholar Publishing, 213-231.

Nyman, Jopi (2003), Postcolonial Animal Tale from Kipling to Coetzee. New Delhi: Atlantic Publishers \& Distributors.

Plumwood, Val (2003), Decolonizing Relationships with Nature. - Decolonizing Nature: Strategies for Conservation in a Post-Colonial Era. Eds William H. Adams \& Marin Mulligan. London: Earthscan, 51-78.

Pratt, Mary Louise (1992), Imperial Eyes: Travel Writing and Transculturation. London: Routledge.

Ray, Sarah J. \& Maier, Kevin (eds) (2017), Critical Norths. Space, Nature, Theory. Fairbanks: University of Alaska Press.

Ryall, Anka, Schimanski, Johan \& Waerp, Henning Howlid (eds) (2010), Arctic Discourses. Newcastle upon Tyne: Cambridge Scholars Publishing.

Rogover, E. S. \& Kolupaeva, M. V. (2005), Tvortšestvo Jurija Rytheu. SPB: Šaton.

Rytheu, Juri (1973), Metatelnitsa garpuna. Moskva: Molodaja gvardija.

Rytheu, Juri (1987), Ostrov nadeždy. Roman. Moskva: Sovremennik.

Rytheu, Juri (2007), Pod sozvezdijem petšali. Roman. Sankt-Peterburg: Nedra.

Said, Edward W. (2011), Orientalismi. Suom. Kati Pitkänen. Helsinki: Gaudeamus.

Slezkine, Yuri 1992. From Savages to Citizens: The Cultural Revolution in the Soviet Far North, 1928-1938. - Slavic Review 51:1, 52-76. https://doi.org/10.2307/2500261.

Slezkine, Yuri (1994), Arctic Mirrors. Russia and the Small Peoples of the North. Ithaca: Cornell University Press.

Smola, Klavdia \& Uffelmann, Dirk (2016), Postcolonial Slavic Literatures after Communism: Introduction. - Postcolonial Slavic Literatures after Communism. Eds Klavdia Smola \& Dirk Uffelmann. New York: Peter Lang, 9-25.

Spivak, Gayatri C. (1988), Can the Subaltern Speak? - Marxism and Interpretation of Culture. Eds Cary Nelson \& Larry Grossberg. Chicago IL: University of Illinois Press, 271-313.

Spivak, Gayatri C. (1994), Responsibility. - boundary 2 21:3, 19-64. https://doi.org/10.2307/303600.

Spivak, Gayatri C. (1999), A Critique of Postcolonial Reason: Toward a History of the Vanishing Present. Cambridge: Harvard University.

Thompson, Ewa (2000), Imperial Knowledge: Russian Literature and Colonialism. Westport: Greenwood Press.

Vlasenko, Aleksandr (1988), Juri Rytheu. Moskva: Sovetskaja Rossija.

Wiget, Andrew \& Balalaeva, Olga (2011), Khanty, People of the Taiga: Surviving the Twentieth Century. Fairbanks: University of Alaska Press.

Wolfe, Cary (2003), Animal Rites: American Culture, the Discourse of Species, and Posthumanist Theory. Chicago: University of Chicago Press.

Wolfe, Patrick (2006), Settler Colonialism and the Elimination of the Native. - Journal of Genocide Research 8:4, 387-409. https://doi.org/10.1080/14623520601056240.

Znamenski, Andrei A. (2003), Shamanism in Siberia: Russian Records of Indigenous Spirituality. Dordrecht: Kluwer Academic Publishers. 